Folia Cardiologica 2018

\title{
Objawy pooperacyjnego zespołu Hornera po korekcji wrodzonej wady serca prowadzące ostatecznie do rozpoznania zespołu Axenfelda-Riegera
}

\section{Postoperative Horner's syndrome after congenital heart surgery finally evolving to Axenfeld-Rieger syndrome diagnosis}

\author{
Julia Haponiuk ${ }^{1,2}$, Ewelina Kwaśniak ${ }^{1}$, Karolina Andrzejczyk ${ }^{3}$, Maciej Chojnicki ${ }^{1}$, \\ Mariusz Steffens ${ }^{1}$, Konrad Paczkowski ${ }^{1}$, Katarzyna Gierat-Haponiuk ${ }^{4}$, \\ Anna Romanowicz ${ }^{1}$, Marta Paśko-Majewska ${ }^{1}$, Ireneusz Haponiuk ${ }^{1,4}$ \\ ${ }^{1}$ Oddział Kardiochirurgii Dziecięcej Szpitala św. Wojciecha w Gdańsku-Zaspie, COPERNICUS PL \\ ${ }^{2}$ II Wydział Lekarski Warszawskiego Uniwersytetu Medycznego \\ ${ }^{3}$ Collegium Medicum w Bydgoszczy, Uniwersytet Mikołaja Kopernika w Toruniu \\ ${ }^{4}$ Katedra Fizjoterapii Wydziału Rehabilitacji i Kinezjologii Akademii Wychowania Fizycznego i Sportu \\ im. Jędrzeja Śniadeckiego w Gdańsku
}

\section{Streszczenie}

Zespół Axenfelda-Riegera (ARS) to rzadki zbiór genetycznie uwarunkowanych wad wrodzonych, dziedziczony w sposób autosomalnie dominujący, dający objawy między innymi w obrębie przedniego segmentu narządu wzroku, twarzy, uzębienia oraz okolic brzucha. Najnowsze publikacje wskazują na możliwość współwystępowania wad narządu wzroku z wrodzonymi wadami serca, najprawdopodobniej o wspólnym podłożu genetycznym. Manifestacja kliniczna w zakresie gałki ocznej jest łudząco podobna do zmian występujących w zespole Hornera (HS), jednak etiologię ARS wiąże się z obecnością mutacji w obrębie genów PITX2 oraz FOXC1. Zespół ten w około 50\% prowadzi do jaskry oraz ślepoty, dlatego u pacjentów z podejrzeniem ARS wskazana jest stała kontrola okulistyczna.

U 14-letniej pacjentki we wczesnym okresie pooperacyjnym po korekcji wrodzonej wady serca - ubytku przegrody międzyprzedsionkowej typu II, wystąpiły dyskretne objawy wskazujące na prawostronny HS, które początkowo wiązano z czasowym wprowadzeniem szyjnej kaniuli centralnej. Jednocześnie stwierdzono odczynowy płyn w osierdziu, który ustąpił po intensyfikacji leczenia farmakologicznego. Diagnostyka okulistyczna potwierdziła cechy hipoplazji zrębu tęczówki, na jej podstawie wysunięto podejrzenie ARS. W wykonanym badaniu optycznej koherentnej tomografii (OCT) nerwu wzrokowego nie stwierdzono świeżych zmian, zalecono stałą kontrolę okulistyczną, powtarzanie badania OCT oraz ciśnienia śródgałkowego.

Prezentowany przypadek potwierdza opisywany związek występowania ARS z wrodzonymi wadami serca, wskazuje również na konieczność wnikliwej oceny potencjalnych powikłań pooperacyjnych i dodatkowych wad genetycznych.

Słowa kluczowe: wrodzone wady serca, zespół Axenfelda-Riegera, zespół Hornera, kardiochirurgia wad wrodzonych

Folia Cardiologica 2018; 13, 1: 79-82

Adres do korespondencji: dr hab. n. med. Ireneusz Haponiuk, prof. nadzw., Oddział Kardiochirurgii Dziecięcej Szpitala św. Wojciecha Gdańsk-Zaspa, al. Jana Pawła II 50, 80-462 Gdańsk, tel./faks 587684 881/882, e-mail: ireneusz_haponiuk@poczta.onet.pl 


\section{Wstęp}

Historia korekcji wrodzonej wady serca pod postacią ubytku w przegrodzie międzyprzedsionkowej (ASD, atrial septal defect) sięga obecnie prawie 70 lat praktyki klinicznej, którą zapoczątkował Murray w Toronto w 1948 roku, wykonując po raz pierwszy operację naprawczą. Szacuje się, że około $7,28 \%$ wszystkich rozpoznanych wad serca w Polsce to ASD typu ostium secundum (ASD typu II). Rozpoznanie tej wady jest jednoznacznym wskazaniem do leczenia [1]. Obecnie najczęściej stosuje się dwie metody postępowania u pacjenta z rozpoznaniem ASD II - przezskórne zamknięcie interwencyjne jako postępowanie z wyboru oraz tradycyjne leczenie kardiochirurgiczne. W przypadku leczenia operacyjnego śmiertelność okołooperacyjna jest bliska zeru, a ryzyko powikłań ograniczone jest do efektów ubocznych krążenia pozaustrojowego oraz następstw znieczulenia ogólnego [1]. Mimo ogromnego doświadczenia w leczeniu kardiochirurgicznym ASD II nadal mogą wystąpić bardzo rzadkie, nieoczekiwane powikłania ze strony innych układów i narządów.

W niniejszej pracy przedstawiono przypadek 14-letniej pacjentki, u której po korekcji wrodzonej wady serca pod postacią ASD II wystąpiły dyskretne objawy zespołu Hornera (HS, Horner's syndrome), które po wnikliwej diagnostyce doprowadziły ostatecznie do rozpoznania bardzo rzadkiego zespołu Axenfelda-Riegera (ARS, Axenfeld-Rieger syndrome).

\section{Opis przypadku}

Pacjentka w wieku 14 lat ze zdiagnozowaną wrodzoną wadą serca pod postacią ASD typu II została zakwalifikowana do przezskórnego zamknięcia ubytku w przegrodzie międzyprzedsionkowej. Zabieg pierwotnie odroczono z powodu wystąpienia idiopatycznego płynu w osierdziu przekraczającego $7 \mathrm{~mm}$ separacji w badaniu echokardiograficznym przezklatkowym. Patologię tę wiązano wówczas z możliwością wystąpienia infekcji nieżytowej zgłoszonej w wywiadzie, pomimo ujemnych laboratoryjnych wykładników zapalnych i braku objawów w badaniu przedmiotowym.

Po ponownym przyjęciu nie stwierdzono obecności płynu w osierdziu, podjęto próbę przezskórnego zamknięcia ubytku metodą przezskórnego wszczepienia implantu. W trakcie zabiegu interwencyjnego odstąpiono od implantacji zatyczki ze względu na wielkość i morfologię ubytku międzyprzedsionkowego. Pacjentka została zakwalifikowana do operacyjnej korekcji wady, zabieg zamknięcia ASD II wykonano podczas tego samego pobytu, bez powikłań.

We wczesnym okresie po wypisie z oddziału kardiochirurgii, przed wyznaczonym terminem planowej kontroli ambulatoryjnej, pacjentka została ponownie przyjęta z powodu stwierdzonego $w$ badaniu echokardiograficznym wolnego płynu w osierdziu o maksymalnej separacji około $13 \mathrm{~mm}$ oraz dyskretnych prawostronnych objawów zwężenia źrenicy i szpary powiekowej, z zapadnięciem gałki ocznej [2]. Obraz wskazywał na prawostronny HS, dalsze postępowanie diagnostyczne rozszerzono o obrazowanie w kierunku ewentualnych zmian w ośrodkowym układzie nerwowym (OUN). Wykonano badanie rezonansu magnetycznego (MRI, magnetic resonance imaging), w którym nie wykryto patologii OUN. Wysunięto podejrzenie jatrogennego HS, spowodowanego najprawdopodobniej założeniem kaniuli centralnej do prawej żyły szyjnej podczas niedawnej indukcji znieczulenia do zabiegu w krążeniu pozaustrojowym. W trakcie diagnostyki okulistycznej wykonano optyczną koherentną tomografię (OCT, optical coherence tomography). Oprócz potwierdzenia zmian w gałce oka prawego makroskopowo imitujących HS wykryto także inne, dodatkowe anomalie, niezwiązane z zespołem. Nieprawidłowości dotyczyły narządu wzroku (embryotoxon posterior, anomalia kąta przesączania, anomalia w budowie tęczówki, i tarczy nerwu II, c/d około 0,6, o nieprawidłowym kształcie mogącym świadczyć o prawdopodobnej jaskrze) oraz twarzoczaszki: szeroki grzbiet kostny nosa, boczne przemieszczenie przyśrodkowych kątów szpary powiekowej (telecanthus) i zwiększony rozstaw oczodołów (hypertelorismus). Zdiagnozowany wolny płyn w osierdziu ustąpił po intensyfikacji leczenia zachowawczego.

Stwierdzone objawy stanowiły podstawę do rozpoznania u pacjentki ARS. Dziewczynkę, zgodnie z zaleceniami, objęto ambulatoryjną opieką okulistyczną. Zalecono regularne konsultacje neurologiczne i okulistyczne związane z towarzyszącym ARS ryzykiem wystąpienia wczesnej jaskry, stałą kontrolę okulistyczną, powtarzanie badania OCT oraz ciśnienia śródgałkowego. W razie wystąpienia objawów wczesnej jaskry przygotowano wstępny plan celowanego leczenia farmakologicznego bądź operacyjnego.

\section{Dyskusja}

Zespół Hornera to bardzo rzadkie, najczęściej jatrogenne powikłanie pooperacyjne w kardiochirurgii wad wrodzonych wynikające z naruszenia współczulnego unerwienia oka. Głównymi objawami HS są: zwężenie źrenicy (ptosis), zwężenie szpary powiekowej (miosis) i zapadnięcie gałki ocznej (enophtalamus) [2]. Mimo opisywanych przypadków występowania tego zespołu po operacjach kardiochirurgicznych [3], nie należy ograniczać dogłębnej diagnostyki zmian w zakresie gałki ocznej, gdyż nie można wykluczyć ryzyka wystąpienia innych, potencjalnie groźnych nieprawidłowości związanych z narządem wzroku.

Zespół Axenfelda-Riegera to zbiór objawów mających podłoże w rzadkich zaburzeniach genetycznych, mogący występować w młodym wieku, związany z ryzykiem wczesnej jaskry. W aktualnie obowiązującym mianownictwie niepra- 
widłowości te określane są przez trzy eponimy. Pierwszy z nich to anomalia Axenfelda, która charakteryzuje się nieprawidłowością w obrębie linii Schwalbego, tak zwaną embryotoxon posterior, w której jaskra występuje w niewielu przypadkach. Anomalia Riegera natomiast to embryotoxon posterior z towarzyszącymi nieprawidłowościami w obrębie kąta przesączania oraz tęczówki, z jaskrą rozwijającą się w około 50\% przypadków. W zespole Riegera oprócz objawów występujących w anomalii o tym samym eponimie, możliwe są także nieprawidłowości związane z uzębieniem: mała liczba zębów (hypodontio) i małe zęby (microdontio), budową twarzoczaszki: szeroki rozstaw oczodołów (hypertelorismus), szeroki grzbiet kostny nosa, szeroki rozstaw przyśrodkowych kątów szpar powiekowych (telecanthus) oraz objawów z innych okolic ciała, jak na przykład nadmiar skóry wokół pępka [4].

Pierwsze doniesienia o możliwości współwystępowania ARS z wrodzonymi wadami serca oparte na publikacjach datuje się na 2010 rok. Zwrócono wówczas uwagę na możliwość dziedziczenia obu tych zaburzeń w sposób autosomalnie dominujący, na podstawie analizy trzech pokoleń rodziny ze zdiagnozowanym ARS, oraz wrodzonych wad serca pod postacią dwupłatkowej zastawki aortalnej lub ubytku w przegrodzie międzyprzedsionkowej typu ASD II [5]. Kolejna i - według dostępnej nam wiedzy - ostatnia, jak dotychczas, opublikowana w 2013 roku praca na ten temat potwierdzała powiązania genetyczne pomiędzy ARS i wrodzonymi wadami serca. W publikacji Gripp i wsp. [6] wskazano również na mutacje w obrębie genów PITX2 oraz
FOXC1 - jako prawdopodobną przyczynę występujących nieprawidłowości.

U prezentowanej pacjentki zdiagnozowano część z wymienionych objawów, co pozwoliło na wysunięcie podejrzenia ARS. Jednoznaczne potwierdzenie wymaga szczegółowych badań genetycznych rozszerzonych o badania rodzinne, które na obecnym etapie postępowania nie były konieczne. Zdecydowanie natomiast wstępne rozpoznanie lub choćby podejrzenie ARS w młodym wieku pacjenta może okazać się wartościowe ze względu na konieczność wdrożenia regularnej oceny okulistycznej i wczesnego leczenia jaskry.

Prezentowany przypadek potwierdza związek występowania ARS z wrodzonymi wadami serca, stanowi kolejny argument wskazujący na potrzebe dalszych obserwacji i badań populacyjnych umożliwiających szczegółową klasyfikację tych nieprawidłowości i ustalenie sposobów profilaktyki i leczenia.

\section{Wnioski}

1. Prezentowany przypadek potwierdza związek występowania ARS z wrodzonymi wadami serca, wskazuje również na konieczność wnikliwej oceny potencjalnych powikłań pooperacyjnych, mogących wynikać z dodatkowych wad genetycznych. 2. Przykład pacjentki sugeruje konieczność wnikliwej oceny obserwowanych powikłań pooperacyjnych, mogących wskazywać na dodatkowe zespoły wad genetycznych, stanowiących odmienne zagrożenia dla pacjenta.

\section{Abstract}

Axenfeld-Rieger syndrome (ARS) is an uncommon, autosomal dominant disorder characterized by anomalies of the anterior segment of the eye, face, teeth, and abdominal region. The coincidence of congenital heart defects and eye anomalies have been recently reported, as well as the genetic origin of these disorders. Clinical manifestation of the both the Horner's and ARS resemble very similar therefore they could be easily misdiagnosed. The ARS is induced by spontaneous mutations in PITX2 and FOXC1 genes though. As in 50\% cases of ARS the glaucoma develops, permanent ophthalmological care is necessary.

14-years-old patient in an early postoperative course after successful ostium secundum atrial septal defect surgery was observed with mild, iatrogenic Horner's syndrome which coexisted with increased pericardial fluid. The ophthalmological examination revealed the iridial dysgenesis suggesting the ARS diagnosis. There were no recent abnormalities found in the optical coherent tomography (OCT) of the optic nerve. Thus, further OCT repeats and intraocular pressure measures under ophtalmological supervision were deputed.

This case report confirms the coexistence of ARS and congenital heart defects, and emphasize the need of meticulous examination of any possible postoperative complications, and additional genetic defects.

Key words: congenital heart defects, Axenfeld-Rieger syndrome, Horner's syndrome, pediatric cardiac surgery

Folia Cardiologica 2018; 13, 1: 79-82 


\section{Piśmiennictwo}

1. Religa Z, Skalski J, Haponiuk I. Ubytek przegrody międzyprzedsionkowej oraz częściowy nieprawidłowy spływ żył płucnych. In: Religa Z, Skalski J, Haponiuk I. ed. Kardiochirurgia dziecięca. Wydawnictwo Naukowe, Katowice 2003: Katowice.

2. Kaya SO, Liman ST, Bir LS, et al. Horner's syndrome as a complication in thoracic surgical practice. Eur J Cardiothorac Surg. 2003; 24(6): 1025 -1028, doi: 10.1016/j.ejcts.2003.09.014, indexed in Pubmed: 14643824.

3. Nasser BA, Mesned A, Moazamy YE, Kabbani MS. Horner's syndrome after paediatric cardiac surgery: case report and review of the literature. Cambridge University Press, 2014.
4. Zagórski Z, Naumann GO. Choroby rogówki, twardówki i powierzchni oka. Wyd. 1. Wydawnictwo Czelej, Lublin.

5. Akkus MN, Argin A. Congenital heart defects in two siblings in an Axenfeld-Rieger syndrome family. Clin Dysmorphol. 2010; 19(2): 56-61, doi: 10.1097/MCD.0b013e328335c1ce, indexed in Pubmed: 20179581.

6. Gripp KW, Hopkins E, Jenny K, et al. Cardiac anomalies in AxenfeldRieger syndrome due to a novel FOXC1 mutation. Am J Med Genet A. 2013; 161A(1): 114-119, doi: 10.1002/ajmg.a.35697, indexed in Pubmed: 23239455. 